
ОСОБЛИВОСТІ ДИСТАНЦІЙНОГО НАВЧАННЯ У ВОКАЛЬНО-ПЕДАГОГІЧНІЙ
ДІЯЛЬНОСТІ МАЙБУТНЬОГО ВЧИТЕЛЯ МУЗИЧНОГО МИСТЕЦТВА

\title{
CHARACTERISTICS OF DISTANCE LEARNING IN VOCAL AND PEDAGOGICAL ACTIVITY OF THE FUTURE MUSIC ART TEACHER
}

УДК 378.018.43:784

DOI https://doi.org/10.32843/2663-

6085/2020/25-1.39

\section{Лановенко-Мельник Н.В., заслужена артистка України, викладач кафедри вокально-хорової підготовки, теорії та методики музичної освіти}

\section{Басовська С.Ю.,} викладач кафедри вокально-хорової підготовки, теорії та методики музичної освіти

\section{Остапчук Л.О.,}

заслужена артистка України,

старший викладач

кафедри вокально-хорової підготовки,

теорії та методики музичної освіти

\section{Плакидюк О.Ю.,}

\section{викладач}

кафедри вокально-хорової підготовки, теорії та методики музичної освіти

\section{Хохлан В.О.,}

викладач касредри вокально-хорової підготовки, теорії та методики музичної освіти

Вінницького державного педагогічного університету імені Михайла Коцюбинського

\begin{abstract}
Стаття має теоретичну спрямованість, у ній висвітлена позиція авторів щодо ефрективності дистанційного навчання під час освітнього прочесу. Охарактеризовано стрімкий розвиток дистанційного навчання в освіті, зокрема у викладанні вокалу у вищих навчальних закладах. Одним із актуальних напрямів розбудови сучасної вищої освіти є впровадження технологій дистанційного навчання у навчальний прочес. Дистанційна фоорма навчання дає можливість створення систем безперервного навчання, загального обміну інфрормацією. у статті розглянуто переваги та недоліки методів навчання, що базуються на дистанційних технологіях у профессійній вокальній освіті. Виконано порівняння дистанційного навчання із класичними методами очного та заочного навчання. Висвітлено тенденції розвитку сучасної вокальної освіти у вищих навчальних закладах. За допомогою SWOT-аналізу охарактеризовано сильні та слабкі сторони дистанційного навчання, враховані усі загрози та можливості, що виникають під час дистанційного навчання. Проведено дослідження серед студентів кафредри вокально-хорово підготовки, теорії та методики музичної освіти Вінницького державного педагогічного університету імені Михайла Коцюбинського щодо доцільності й ефрективності навчання із застосуванням різних цифррових інструментів дистанційного навчання. У статті також розглядається питання в контексті розвитку професійної діяльності педагога з вокалу за умов дистанційного навчання: як і яким чином адаптувати освітню програму в нове сучасне освітне середовище із застосуванням інфоормаційно-комунікаційних технологій. Охарактеризовано основні ключові компетентності викладачів вокалу в організації дистанційного навчання. Автори зосереджують увагу на необхідності цілеспрямовано та системно фоормувати відповідні компетенції педагогів у контексті дистанчійного навчання студентів.
\end{abstract}

Ключові слова: вокально-педагогічна діяльність, дистанційне навчання, онлайннавчання, цисрові інструменти, ключові компетентності.

The article has a theoretical focus, it highlights the position of authors on the effectiveness of distance learning in educational process. The rapid development of distance learning in education, in particular in the in higher voice coaching. One of relevant directions of development of modern higher education is the introduction of distance learning technologies in the educational process. Remote forms of training makes it possible to create lifelong learning systems, general exchange of information. The article discusses the advantages and disadvantages of distance learning methods based on professional vocal education. The comparison of distance learning with classical methods of full-time and distance learning is performed. The tendencies of development of modern vocal education in higher educational establishments are covered. With the help of SWOT-analysis the strengths and weaknesses of distance learning are described, all threats and opportunities that arise during distance learning are taken into account. The study was conducted among students of the Department of Vocal and Choral Training, Theory and Methods of Music Education of Vinnytsia State Pedagogical University named after Mykhailo Kotsyubynsky on the feasibility and effectiveness of learning using various digital distance learning tools. The article also considers the question in the context of the development of professional activity of a voice teacher in the conditions of distance learning: how and how to adapt the educational program to the new modern educational environment with the use of information and communication technologies. The main key competencies of voice teachers in the organization of distance learning are described. The authors focus on the need to purposefully and systematically form the relevant competencies of teachers in the context of distance learning.

Key words: vocal and pedagogical activity, distance learning, online learning, digital tools, key competencies.
Постановка проблеми у загальному вигляді. У зв'язку із ситуацією, що склалася у світі, зокрема і в Україні, а саме за умов пандемії коронавірусу, особливої уваги вимагає проблема ефективності дистанційного навчання. Дистанційне навчання - це новий досвід роботи, що зайняв вагоме місце в освітньому середовищі з огляду на останні події. Питання дистанційної освіти сьогодні $€$ особливо актуальним, оскільки елементи дистанційного навчання впроваджуватимуться в українську систему освіти на постійній основі, навіть якщо навчальні заклади запрацюють у повноцінному режимі.

Аналіз останніх досліджень і публікацій. Важливе значення цієї проблеми зумовлене тим, що відкриваються нові перспективи для підвищення ефеективності освітнього процесу. Велика роль надається самоосвіті, дистанційним освітнім програмам. Історія дистанційного навчання розпочинається ще 3 далекого 1840 р., коли англійський педагог-винахідник Ісаак Пітман навчав студентів, використовуючи поштові відправлення. Проблемам дистанційного навчання присвячені наукові праці багатьох науковців, серед них Р. Деллінг, М. Томпсон, А.Є. Петров, А.В. Хуторський, Т.А. Чернишева, С.С. Аксенова. Досліджуючи погляди учених, можна визначити, що дистанційне навчання - це нова, специфічна форма навчання, дещо відмінна від звичних фрорм очного 
або заочного навчання. Вона передбачає інші засоби, методи, організаційні форми навчання, іншу форму взаємодії викладача і студента, студентів між собою [1, с. 3]. 3 огляду опрацьованих літературних джерел можна зробити висновок, що у проведених дослідженнях недостатньо приділяється уваги дистанційній фрормі навчання, зокрема у професійній вокальній освіті.

Мета статті - проаналізувати особливості дистанційного навчання у вокально-педагогічній діяльності та визначити переваги і недоліки його функціонування у підготовці майбутнього вчителя музичного мистецтва. Для досягнення мети нами були використані різні методи дослідження: аналіз, узагальнення, порівняння тощо.

Виклад основного матеріалу. Одним із провідних завдань, що стоять перед викладачами та працівниками ВН3, є не тільки впровадження системи дистанційної освіти, а й забезпечення сприятливого впливу нових технологій на освітній процес, тобто необхідність розвитку сильних сторін і мінімізація негативних. Розглянемо, як трактують поняття «дистанційне навчання» різні літературні джерела. Дистанційне навчання - це форма навчання 3 використанням комп'ютерних і телекомунікаційних технологій, які забезпечують інтерактивну взаємодію викладачів і студентів на різних етапах навчання і самостійну роботу 3 матеріалами інформаційної мережі [4, с. 320]. Дистанційне навчання - одержання освітніх послуг на відстані, без відвідування ВН3, за допомогою нових комп'ютерних і комунікаційних технологій, воно є універсальною, синтетичною, інтегральною, гуманістичною фрормою навчання, що створює умови для студентів та адаптована до базового рівня знань і контрольних цілей студентів [2, с. 62].

У ході проведеного дослідження можна виділити такі переваги та недоліки дистанційного навчання. Для того, щоб чітко зрозуміти можливі перспективи та наявні проблеми дистанційного навчання, використаємо метод аналізу сильних і слабких сторін у викладанні вокалу (табл. 1).
SWOT-аналіз дає можливість проаналізувати усі сильні та слабкі сторони дистанційного навчання у викладанні вокалу, врахувати можливості та загрози.

Водночас потрібно розуміти, що викладач і студент залишаються активними учасниками процесу дистанційного навчання, під час якого можна використовувати різні цифрові інструменти, зокрема:

Платформа Zoom - дає можливість створювати відеоконференції зі студентами. За наявності гарного технічного забезпечення $€$ можливість проведення якісних практичних занять із вокалу. Безкоштовна версія дає можливість охопити аудиторію до 100 чоловік. $€$ можливість займатися 3 кожним студентом індивідуально. Час, відведений у безкоштовній версії, становить до 45 хв.

Google-фоорма - може збирати відповіді студентів і потім проводити автоматичне оцінювання тестування. Цей інструмент дистанційного навчання найбільш підходить для опрацювання і перевірки теоретичного матеріалу з вокалу.

Для опрацювання теоретичного матеріалу можна також використовувати й інші інструменти, зокрема: classtime, learningapps, moodle, my test.

Для отримання зворотного зв'язку зі студентами викладач вокалу може використовувати стандартний сервіс інтернету - електронну пошту, що забезпечує передавання повідомлень як у фрормі звичайних текстів, так і у відеофайлах. Недоліком $€$ те, що студент не має можливості завантажити інфрормацію у великих об'ємах.

Соціальні мережі та месенджери дозволяють створювати закриті групи, чати, теми, що значно полегшують роботу викладача з вокалу.

Для оцінювання індивідуальних досягнень студентів може бути використане портфоліо. Портфоліо - це накопичувальна система оцінювання досягнень студентів (накопичування різних видів робіт, які показують рух в індивідуальному розвитку).

Розглянемо сприйняття дистанційного навчання студентами. Об'єктом дослідження були студенти кафедри вокально-хорової підготовки, теорії та методики музичної освіти Вінницького державного

Таблиця 1

SWOT - аналіз дистанційного навчання у викладанні вокалу

\begin{tabular}{|c|c|}
\hline $\begin{array}{l}\text { Переваги } \\
\text { - Можливість отримання знань особами з особливими } \\
\text { потребами. } \\
\text { - Отримання знань у коморортних умовах для студентів. } \\
\text { - Можливість бути учасником різних вебінарів і відео- } \\
\text { конореренцій за участю професійних викладачів. } \\
\text { - Висока самоорганізація. }\end{array}$ & $\begin{array}{l}\stackrel{\text { Недоліки }}{l} \\
\text { - Недостатній контроль над засвоєнням студентами } \\
\text { одержаних знань. } \\
\text { - Недосконале відтворення звуку технічними засо- } \\
\text { бами. } \\
\text { - Проблема ідентифікації студентів при здачі теоре- } \\
\text { тичного матеріалу. } \\
\text { - Недостатній рівень самоорганізації. }\end{array}$ \\
\hline $\begin{array}{l}\stackrel{\text { Можливості }}{\text { - Організація навчання за допомогою різних циоррових }} \\
\text { інструментів. } \\
\text { - Зменшення часу на перевірку теоретичного матеріалу. } \\
\text { - Ефрективне поєднання дистанційного навчання із } \\
\text { класичним. }\end{array}$ & $\begin{array}{l}\frac{\text { Загрози }}{\text { - Ризик закріпити «гортанні навички», вузли на }} \\
\text { зв'язках, незмикання. } \\
\text { - Відсутність мережі інтернет у віддалених куточках. } \\
\text { - Технічні перебої. }\end{array}$ \\
\hline
\end{tabular}


педагогічного університету імені Михайла Коцюбинського. У дослідженні взяли участь 42 особи.

У процесі дослідження з'ясували, що абсолютно неефективним дистанційне навчання вважають 6 студентів. Ще 9 студентів також говорять про неефективність дистанційного навчання. 20 респондентів, що складає 47,62\% від загальної кількості опитаних, вважають дистанційне навчання еорективним, але в поєднанні із класичним навчанням. Кількість учасників, які повністю задоволені дистанційними технологіями, склала 16,7\% (7 студентів).

Порівняємо дистанційне навчання із класичними методами очного та заочного навчання під час викладання вокалу (табл. 2).

Порівнюючи дистанційне навчання із класичним, можна однозначно сказати, що дистанційна форма навчання студентів найкраще підходить до вивчення саме теорії музики, історії, аналізу творчості композиторів. Доцільність впровадження освітніх комунікаційних технологій в освітній процес є очевидною, зокрема таких, як проведення в онлайн-режимі групових та індивідуальних вебінарів, майстер-класів, дискусій на фрорумах, виконання тестових завдань тощо. Мультимедійні технології, подача матеріалу в багаторівневому просторі з використанням інтерактивних методів надають широкі можливості для навчального процесу дистанційного формату. Водночас впровадження цих технологій в індивідуальні практичні заняття вокалістів викликають певні заперечення. Зауважимо, що проведення практичних занять у віддаленому режимі для вокалістів є недоліком дистанційної форми навчання, оскільки процес формування співочих навичок у студентів $€$ дуже суперечливим і сумнівним, адже педагог несе велику відповідальність за забезпечення гігієни голосу під час процесу вокальної підготовки студентів [7, с. 183]. Його головною метою $є$ слідкування за дотриманням студентом плавного, рівного звучання на диханні та в жодному разі не допускати фрорсування звуку під час співу, а це не завжди вдається простежити під час уроку в онлайн-режимі, оскільки майже в усіх інтернетплатформах відсутня передача якісного звуку.

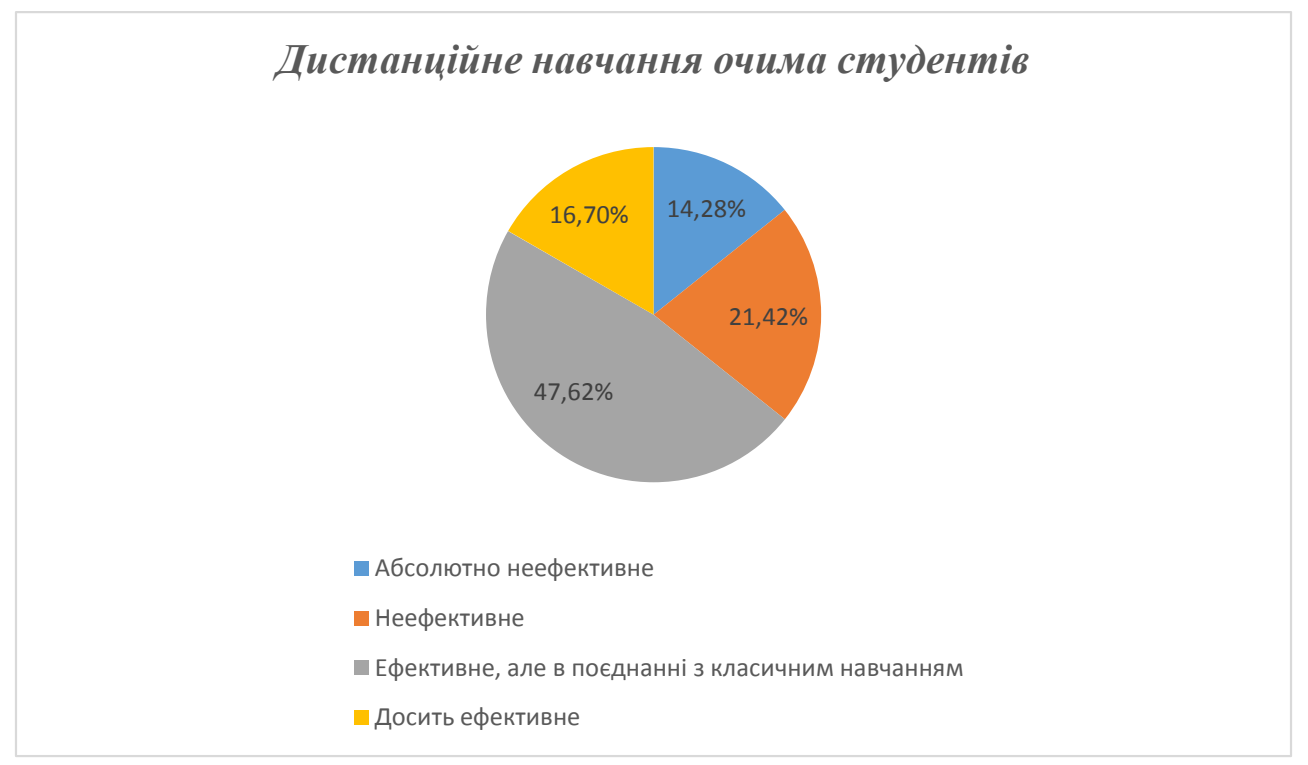

Рис. 1. Дистанційне навчання очима студентів

Таблиця 2

Порівняльна характеристика дистанційного й очного навчання

\begin{tabular}{|l|c|c|}
\hline \multicolumn{1}{|c|}{ Фактори } & $\begin{array}{c}\text { Очне, заочне } \\
\text { навчання }\end{array}$ & $\begin{array}{c}\text { Дистанційне } \\
\text { навчання }\end{array}$ \\
\hline Особливий психологічний контакт між викладачем і студентом. & + & - \\
\hline Особлива енергетика присутності слухача. & + & - \\
\hline Відчуття простору концертної зали й акустики. & + & - \\
\hline Можливість бути учасником вебінарів, майстер-класів. & - & + \\
\hline Живийлінструмент. & + & - \\
\hline Організація творчих онлайн-зустрічей із видатними вокалістами. & - & + \\
\hline Наближення до реальної практичної атмосрери. & + & - \\
\hline Можливість доступу до онлайн-ресурсів найкращих університетів. & - & + \\
\hline
\end{tabular}


Це можливо лише за наявності профресійної звукової апаратури. Академічна постановка голосу $€$ надійною основою для подальшої орієнтації та ствердження себе як вокаліста [5, с. 101].

Профресійні програми, присвячені навчанню вокаліста, а саме індивідуально-практичної складової частини, зустріти досить важко, якщо не сказати, що вони зовсім відсутні. Відомо, що індивідуальні практичні заняття вимагають створення специфрічних умов для їх проведення. Наприклад, особливого психологічного й емоційного контакту між викладачем і студентом. Відсутність цього контакту, безумовно, змінює характер дистанційної фрорми навчання. Сьогодні ще жодні мультимедійні технології не можуть цього запропонувати, адже вміння встановлювати психологічний контакт вчителя зі студентами у процесі вокальної діяльності $€$ одним із важливих комунікативним умінь [3, с. 58]. Крім того, навчання вокаліста передбачає фрормування цілого ряду умінь і навичок, набутих в умовах, наближених до реальної практичної діяльності. Це і акустика залу, відчуття особливої психологічної атмосфери й енергетики присутності слухача.

Дистанційне навчання може широко застосовуватися як комбінований вид навчання, тобто зі збереженням класичних фрорм і методів навчання. Таким чином, з метою вдосконалення практичної складової частини виконавської діяльності можна говорити лише про часткове використання дистанційної форми навчання. За комбінованого навчання очні заняття чергуються з дистанційними. Подібні моделі викладання вже сьогодні можна зустріти у вищих навчальних закладах України.

Якість дистанційних занять залежить не тільки від учасників процесу, а й від подальшого прогресу сучасних мультимедійних технологій, розвиток яких не стоїть на місці. Можливо, сучасні технології незабаром будуть здатні передавати емоції, темперамент, характер виконавського процесу. Зазвичай дистанційне навчання здійснюється із застосуванням традиційних освітніх технологій, де поряд 3 індивідуальними практичними заняттями відбувається відвідування майстер-класів видатних вокалістів, організація творчих зустрічей. Перенесення деяких із цих фрорм, зокрема практичної складової частини, в дистанційну площину вимагає часу та безліч зусиль.

На підставі цього процес дистанційного навчання вимагає високого професійного рівня викладача, прагнення до співпраці з колегами та студентами на шляху досягнення якісних результатів освіти.

Хочемо звернути увагу на те, що за стрімкого розвитку інформаційно-комунікаційних технологій викладач вокалу повинен постійно розвиватися та самовдосконалюватися, а саме:

- систематично проходити курси підвищення кваліфікації;
- бути активним учасником вебінарів, майстеркласів із впровадження дистанційного навчання в освітній процес;

- за можливості створювати лекції-візуалізації для студентів, відеоуроки;

- організовувати інтерактивні семінари у формі дискусій;

- освоювати новітні технології, нові платфрорми для впровадження дистанційного навчання в освітній процес;

- залучати студентів для виконання завдань і самостійної роботи на платорормах Classtime, Googleclass, My Test тощо.

- здійснювати обмін досвідом із іншими викладачами вищих навчальних закладів України і не тільки.

Висновки. Проаналізувавши доцільність застосування дистанційної фрорми навчання у майбутніх вчителів музичного мистецтва, зокрема 3 фраху «вокал», ми виявили низку позитивних і негативних аспектів. Так, з одного боку, така фрорма навчання підвищує мотивацію у студентів до власного пошуку необхідних відчуттів у технічних прийомах і характері звуку, створює процес високої самоорганізації, що підвищує творчий та інтелектуальний потенціал. Активізує аналітичне мислення при записі та прослуховуванні власного відеоуроку, а також вдосконалює навички володіння комп'ютером і різними інтернет-платформами. Зі сторони педагогів така форма навчання вимагає універсальної підготовки та володіння сучасними інформаційними технологіями. Студенти заочної форми навчання показали гарний результат, адже організація такого освітнього процесу дає змогу краще проконтролювати самостійну підготовку з фаху, що в рази підвищує успішність навчання під час сесії.

Також було виявлено, що ті студенти, які володіють яскраво вираженими вокальними здібностями, показали кращий результат у процесі дистанційного навчання порівняно 3 тими, хто має дуже посередні вокальні здібності. Тому відсутність безпосередньо живого контакту зі студентом, наявність технічних складнощів проведення онлайн-уроків, відсутність належного технічного забезпечення та інтернет-зв'язку ще раз підтверджує, що дистанційна форма навчання для мистецьких закладів освіти та для ВНЗ, які здійснюють підготовку вчителів музичного мистецтва, не $\epsilon$ еорективним, а може існувати тільки як допоміжний і частковий засіб підвищення результативності профресійної фрахової підготовки.

\section{БІБЛІОГРАФІЧНИЙ СПИСОК:}

1. Адамова І., Головачук Т. Дистанційне навчання: сучасний погляд на переваги та проблеми. Витоки педагогічної майстерності. 2012. № 10. С. 3-6.

2. Блощинський І.Г. Сутність та зміст поняття «дистанційне поняття» в зарубіжній та вітчизняній 
літературі. Вісник Національної академії Державної прикордонної служби України. 2015. Вип. 3 С. 59-64.

3. Василевська-Скупа Л.П. Формування комунікативної компетентності майбутніх учителів музичного мистецтва : монографрія. Вінниця : ТОВ фрірма «Планер», 2014. 208 с.

4. Веремчук А. Проблеми і перспективи дистанційного навчання у ВНЗ. Проблеми підготовки сучасного вчителя. 2013. № 7. С. 319-325.

5. Красовська Л.О. Сучасний вокал: методи навчання в різних жанрах музичного мистецтва. Культура України. 2016. № 53. С. 100-106.
6. Коханська Т.В. Переваги та недоліки дистанційної освіти в умовах розвитку інфрормаційних технологій та комунікацій. Проблемы использования инорормационных технологий в сорере образования, науки и промышленности : 10-я международная конференция, 30-31 января 2013 г., Днепропетровск, 2013. C. $142-144$.

7. Чернышева Т.А. Дистанционная фрорма обучения в дополнительном профессиональном образовании музыканта-исполнителя. Вестник СПбГУКИ. 2017. № 3. С. 180-183. 